\title{
Food Security amidst the Climate Change Scenario Perspectives, Issues and Opportunities in Mountain Agriculture
}

\author{
Vir Singh* \\ Department of Environmental Science, GB Pant University of Agriculture \& Technology, India
}

Submission: March 03, 2018; Published: April 19, 2018

*Corresponding author: Vir Singh, College of Basic Sciences and Humanities, GB Pant University of Agriculture \& Technology, Pantnagar - 263145, Uttarakhand, India, email: drvirsingh@rediffmail.com; sinvir@gmal.com

\begin{abstract}
Climate change is looming large on planet earth and its impacts are being increasingly felt in all the ecosystems in one way or the other. Its' impact is bound to induce phenomenal changes in agriculture. Any alteration in our food production system would inevitably affect food security of the masses. Food security and the ecological security go hand in hand. A sustainable food production depends on the ecological wellbeing of an ecosystem (cropland ecosystem or agro-ecosystem). Ecological security translates into food security. Sustainable food flows are ensured so long as ecological sustainability of an agro-ecosystem is ensured. Amidst the climate change scenario, we need to adopt adaptation mechanisms in agriculture. India is endowed with extremely high degree of biodiversity, including agro-biodiversity. Among the climate-resistant crops are the ones being still cultivated in marginal areas, such as in the mountains and in many tribal areas? Yet there are numerous landraces in many areas which have been performing well under adverse environmental conditions. Crops being raised for millennia under rain-fed conditions could be promising under climate change conditions. Organic farming could be a boon both for the health of agro-ecosystems and agro-economy. Large geographical areas under natural forests would provide resilience to agriculture and contribute to sustain food security.
\end{abstract}

Keywords: Adaptation; Agriculture; Agro-biodiversity; Climate change; Ecological integrity; Food security; Organic; Farming

\section{Introduction}

Climate change is looming large on the globe. Food security is one of the key issues that inevitably needs to be resolved under the specters of climate change, particularly in the fragile ecosystems, such as the Himalayan mountains, where climate change is more pronounced than in the plain areas and where adaptation mechanisms are vocal but need to be promoted, enhanced and implemented as an appropriate response to the climate change becoming increasingly phenomenal.

Mountains, especially the Himalayan Mountains, constitute one of the most fragile ecosystems on planet Earth. However, their ecological and environmental functions are vital for the mainstream world constituted largely of the plains. Biodiversity, one of the most unique attributes of natural evolution, is a unique characteristic of the mountains. Agriculture, which has been and continues to be one of the greatest concerns of humanity on Earth since time immemorial, in a sense, is an art of biodiversity management. Farmers have been manipulating, managing, enriching, promoting, and utilizing biodiversity for deriving their livelihoods for ages. This biodiversity, and consequently mountain agriculture, owing to global warming, are under unprecedented environmental stress these days.
Climate change is affecting - as it is bound to do - life, including human life, throughout the globe. It is especially evident in the Himalayan Mountains. The Himalayas may be referred to as the Third Pole, for the largest amount of snows and ice is concentrated in the Greater Himalayan area of these mountains, which is only next to the two poles. Warming in the Himalayan region is reported to be more than the global average. It is also true that the mountain inhabitants contribute a little to the global warming, but they are slowly heading towards being the first and perhaps the worst victims of global warming being followed by adverse climate change. The global warming is to severely affect water supplies, biodiversity, and agricultural production and is also bound to give a severe blow to several other factors that form the basis of a happy and content life. Severe climate change impact on Himalayan Mountains would be linked with the impending economic blues in the plains.

What should we do amidst the gloom of climate change? This article attempts to look into some important adaptation mechanisms that could respond to the on-going spell of climate change and help avert the impending disaster. 


\section{Climate Change and the Himalayas}

Climate change is looming large on planet earth and its impacts are being increasingly felt in all the ecosystems in one way or the other. Its impact in the Himalayan Mountains, like in the poles, is bound to induce phenomenal changes in other ecosystems. Himalayan mountains provide origin to perennial river systems in South Asia and therefore climate change repercussions in the Himalayan Region ought to have profound implications for global climate as well as for global economies.

Himalayan glaciers cover about three million ha, or, 17\% of the global mountain area - the largest bodies of ice outside the polar caps. Total area of Himalayan glaciers is $35,110 \mathrm{~km}^{2}$. The total ice reserve of these glaciers is $3,735 \mathrm{~km}^{3}$, which is equivalent to $3250 \mathrm{~km}^{3}$ of fresh water. Himalayan mountains are the source of the nine giant river systems of Asia: the Indus, Ganga, Brahmaputra, Irrawaddy, Salween, Mekong, Yangtze, Yellow and Tarim. Himalaya serves as the water lifeline for 500 million inhabitants of the region, or about 10 percent total regional human population, according to IPCC.

Spell of global warming on these mountains would lead to declined water flows, drying up of some of the important rivers, especially the rainfed ones, giving a severe blow to food production and livelihood security of millions of people. Growing evidence shows that the glaciers of the Himalayas are receding faster than in any other part of the world. For example, the rate of retreat of the Gangotri glacier over the last three decades has been more than three times the rates of the retreat during the preceding two hundred years.

\section{Dynamics of Indian Agriculture}

Fate of humanity is intertwined with agriculture, which encompasses cropping, animal husbandry, horticulture, forestry, fishery, and all other land-related activities. Indian agriculture, undoubtedly the oldest one in the world, has undergone three phases in its history and has now ushered in the third phase. These are the following:

i. Primitive agriculture

ii. Traditional agriculture

iii. Green Revolution agriculture

iv. LPG agriculture

The primitive agriculture was largely dependent on uncultivated lands. Natural forests used to be the sources of a variety of foods. The foods were consumed uncooked. However, man had learnt to plough the land and cultivate food grains. But there was a perfect ecological balance. There was no stress whatsoever on nature thanks to anthropogenic activities. People depended on diversity of foods which was derived from thousands of varieties mostly uncultivated. Primitive agriculture never knew what venerability was. It was extremely resilient and ecologically sustainable.
During the millennia-old history of traditional agriculture farmers maintained a balance between uncultivated lands (forests, grasslands, rangelands, etc.) and cultivated lands. One of the most striking features of Indian traditional agriculture was that it always embraced wonderful biodiversity. Traditional farmers during this period developed an art of cultivating, enhancing, conserving and utilizing biodiversity of nature. This agriculture depended on draught animal power and organic inputs but maintained an ecological balance. Nutritive value and therapeutic qualities of food products were inherent in traditional food production. This agriculture was not dependent on market to a great extent, but bartering system was very strong.

Then, towards the end of the 1960s, India ushered in the often talked-about Green Revolution. This agriculture focused merely on high productivity which became possible with highyielding varieties of crops, indiscriminate use of chemical fertilizers and pesticides, excessive use of water, and fossilfuel powered machinery, like tractors, combine-harvesters, etc. The Green Revolution through altered agronomic practices was one of the proudest achievements at food production fronts turning the country from food importer to a robust food exporter. This agriculture did not have any kind of positive relationship with the environment. Green Revolution also led to a spurt in industries involved in the manufacture of agrichemicals, which also contributed to deteriorate environment.

The agriculture being vigorously pursued these days can be referred to as the liberalization, privatization and globalization (LPG) agriculture, which, in fact, is an 'improved' version of the Green Revolution. The LPG agriculture is biotechnologydriven and is governed by global market. This is closely allied into global industry and is structured for huge profits by the corporate sector. New crop cultivars which nature had 'failed' to evolve have been created using genetic engineering. Genetically modified organisms (GMOs) of major crops are on way to occupy centre-stage of agriculture. After non-food crop of BT cotton, Bt food crops are in the pipeline. The LPG agriculture ignores environmental issues. This agriculture is still in its infancy but is all set to have unending implications for environment and public health [1].

\section{Vulnerability of Contemporary Agriculture}

Never before in the history has Indian agriculture been as vulnerable and uncertainty-ridden as it is today. A glimpse of the dynamics of Indian agriculture reveals that it has systematically deviated away from its very base, that is, the environment-the prop that nourishes all biological resources. Today's agriculture is valued against the prices it fetches from the market, especially the global market. Its contribution to human health and welfare, ecological integrity, resilience of nature, etc. are grossly neglected [2].

The agriculture had begun going anti-nature since the inception of the Green Revolution, which was based on the so- 
called high-yielding varieties, monocultures, indiscriminate applications of chemical fertilizers and pesticides and overexploitation of water resources for irrigation. None of the farming practices associated with the Green Revolution was environment-friendly. The Green Revolution turned ghastly for small and marginal farmers as well as for the agro-ecosystems it operated in. It poisoned virtually all components of the environment - biotic as well as abiotic, and lands, soils, waters and atmosphere. It started poisoning the whole civilization as well as all living beings.

All kinds of epidemics are virtually linked with agriculture. Healthy food ensures healthy society. Contaminated food ensures a sick society. A sick society cannot be a sustainable society. If the very basis of life, i.e. the producers, become poisoned, all the food chains and food webs in all ecosystems are inevitable to be poisoned. Thus a wrong agriculture becomes a root cause of all the ills of a society.

The kind of agriculture being pursued these days (the LPG agriculture) is the climax of contaminated agriculture. Introduction of alien genes in a plant is a classical example of genetic pollution. Bt crops are able to save themselves because the introduced Bt genes produce poison within the plant that is capable of killing insects. But this is the worst possible natureannihilating method of pest control. The ecological means of plant protection call for management, not extermination, of insect pests. If all the insects are wiped out and done to extinction as the genetically modified crops are set to do, this would be a death knell for nature. The genetically modified organisms (GMOs) do not make any difference between useful and harmful insects (of course, there is nothing like harmful in nature). Pollinators, amidst the enormous diversity of insects, will also be wiped out when large areas of cultivated land are covered by GM crops. This situation would bring death warrant for humanity, for the extermination of pollinators would mean failure of crop production to a great extent.

Agriculture has not just been a source of livelihood, human survival, progress and sustainability, but also a way of life, a potent symbol of a civilization, a culture and a philosophy. With the retrogression of agriculture, we are also bound to witness crumbling of Indian ethos reflected in basic Indian philosophy, the agro-ecophilosophy. Making agriculture healthy, vibrant and sustainable is not only necessary but also an imperative for a healthy, vibrant and sustainable society. It is also an imperative of our destiny.

\section{Mainstream Agriculture vs Mountain Agriculture}

Mountain ecosystems are fragile and witness very high degree of biodiversity. Further, mountain ecosystems play very crucial role which the mainstream plain areas cannot. Mountain ecosystems are altogether different from the plains and so is mountain agriculture. Despite massive agricultural transformations having taken place all over the world, mountain people have not brought transformation to their agriculture to an appreciable extent. Mountain agriculture, despite intensive institutional intervention, by and large stays traditional. The cropping accommodates biodiversity of plants, both at species and genetic level which change according to the type of agro-ecosystem. Some of the striking characteristics of the mainstream and mountain characteristics are shown in Table 1.

Table 1: Some features of mainstream and mountain agriculture

\begin{tabular}{|c|c|c|}
\hline Features & $\begin{array}{c}\text { Mainstream } \\
\text { Agriculture }\end{array}$ & $\begin{array}{c}\text { Mountain } \\
\text { Agriculture }\end{array}$ \\
\hline Fragility & Moderate & High \\
\hline Farming system & Absent & Present \\
\hline $\begin{array}{c}\text { Diversity/ } \\
\text { Heterogeneity }\end{array}$ & Minimum & High to extreme \\
\hline Complexity & Less & High to extreme \\
\hline Vulnerability & high & Least \\
\hline Resilience & Low & High \\
\hline $\begin{array}{c}\text { Water use efficiency } \\
\text { of crops }\end{array}$ & poor & high \\
\hline Inputs & External & Internal \\
\hline Productivity & Moderate to high & Moderate \\
\hline Sustainability & Poor & High \\
\hline
\end{tabular}

Natural Adaptation Capability in Mountain Agriculture

An agricultural system that embraces features of a sustainable system also carries characteristics of adaptation capabilities. In other words, a more adapted agricultural system is more sustainable. And also, a more adaptable agriculture is more sustainable. In order to be sustainable, agriculture should be:

i. Ecologically sound

ii. Regenerative

iii. Economically viable, and

iv. Socially just.

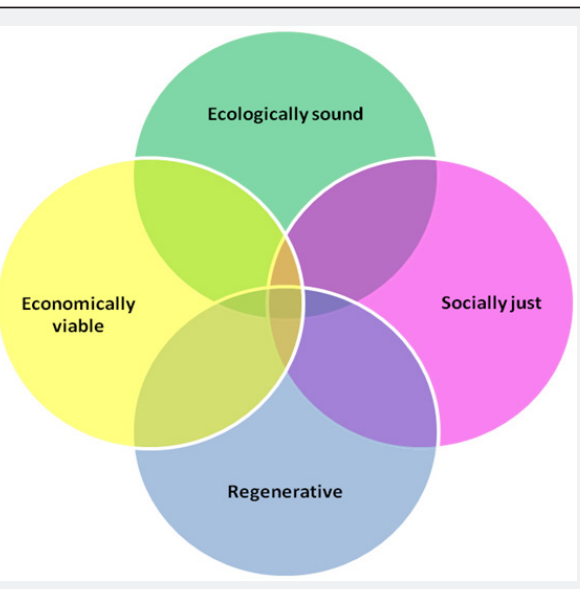

Figure 1: Traits of sustainable agriculture intertwined into a complex whole - High degree of adaptations 
Mountain agriculture, in fact, is characterized by these traits and, therefore, carries traits of a sustainable agriculture. These have been elaborated in Table 2 and have also been demonstrated in Figure 1. All the four traits of a sustainable agriculture are intertwined together. If one trait misses, the very base of sustainability is shrunk. Each trait of a sustainable agriculture, as in case of the mountain agriculture, has many indicators of sustainability.

Table 2: Indicators of sustainability associated with mountain agriculture.

\begin{tabular}{|c|c|}
\hline Sustainability Trait & $\begin{array}{l}\text { Sustainability Indicators Associated } \\
\text { with each Sustainability Trait }\end{array}$ \\
\hline \multirow{9}{*}{ Ecologically sound } & Larger forest-cropland ratio \\
\hline & High degree of biodiversity and complexity \\
\hline & Living soil \\
\hline & Integration with trees and livestock \\
\hline & Energy efficient \\
\hline & Resilient \\
\hline & Cyclic flow of nutrients \\
\hline & Organic inputs \\
\hline & $\begin{array}{c}\text { Resource enhancing and conservation- } \\
\text { oriented }\end{array}$ \\
\hline \multirow{3}{*}{ Economically viable } & Linkages with market \\
\hline & Remunerative production \\
\hline & Value addition \\
\hline \multirow{4}{*}{ Socially just } & Accessibility to food resources by all \\
\hline & Food and nutrition security for all \\
\hline & $\begin{array}{c}\text { Recognition and promotion of traditional } \\
\text { knowledge systems and people's } \\
\text { innovations }\end{array}$ \\
\hline & Good governance \\
\hline \multirow{6}{*}{ Regenerative } & Energy saving and conserving \\
\hline & $\begin{array}{l}\text { Resuscitation and recharging of water } \\
\text { sources }\end{array}$ \\
\hline & Enhanced biodiversity \\
\hline & Enrichment of soil \\
\hline & Increased rate of carbon sequestration \\
\hline & $\begin{array}{l}\text { Contribution to global warming alleviation } \\
\text { and climate change mitigation }\end{array}$ \\
\hline
\end{tabular}

\section{Matrix of Mountain Agriculture}

A mountain agro-ecosystem comprises uncultivated land (often forest or rangeland), cropland, livestock and households as its integrated parts (Figure 2). Uncultivated land serves as a natural reserve of biodiversity, energy, water and nutrients. This is the largest component of a mountain agro-ecosystem. Forests are ecologically more stable than the croplands, hence more resilient and less vulnerable. They do not require an input of nutrients or water. The water received through natural precipitation is conserved and brought into circulation by the forests. Forests are rich reserves of nutrients that also nourish croplands. Forests are capable of regeneration. If forest products are exploited judiciously, they would be capable to regenerate themselves. Higher the measure of biodiversity in a forest ecosystem, greater would be its role in nourishing the croplands. In addition to the ecosystem functions vital for the sustainability of an agro-ecosystem, a forest is also capable of producing very large number of edible food products, such as wild fruits, buds, flowers, seeds, beans, mushrooms, etc. apart from valuable medicinal plants and several other plants of economic value.

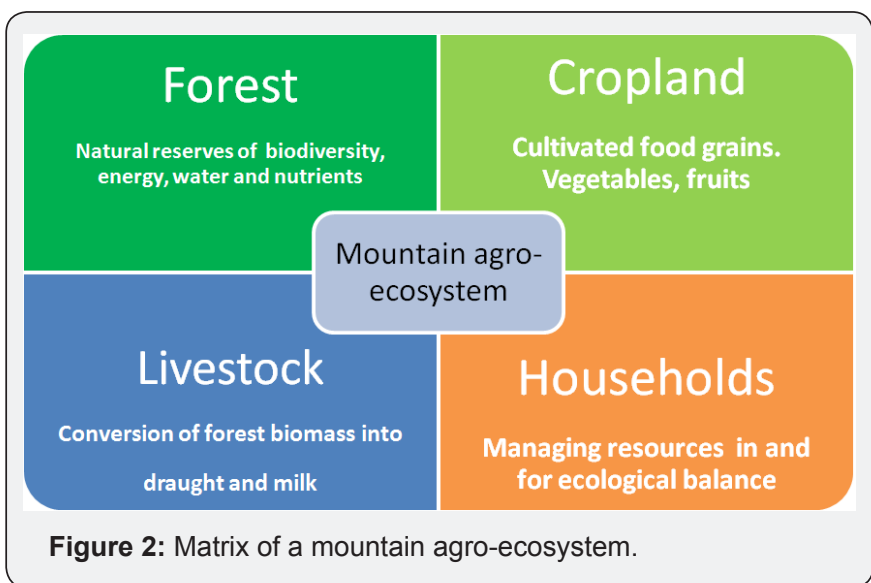

Cropland is the core land serving to produce cultivated foods. This land is constantly nourished by the nutrient stock in a forest ecosystem, either directly (such as through the input of mulch) or through livestock (through manure application).

Mountain agriculture is a mixed agriculture and gives prominent place for the livestock. Livestock play crucial role in transferring nutrients from a forest/rangeland ecosystem to a cropland. The latter are more fragile than the forests. They also help in recycling of nutrients into croplands. Their main contribution is to supply draught power needed for ploughing, leveling, puddling, inter-culture operations, etc. apart from yielding milk as one of the most important food items for human beings. In addition, they also serve as crucial part of the local cultures and as a cushion against socio-economic fluctuations. Livestock role is vital for the very sustainability of mountain agriculture.

A village is a cluster of households, who are the custodians and managers of an agro-ecosystem. They are the farmers who have been at the heart of the evolution of Indian agriculture. Mountain farmers are a rich repository of Indian wisdom. They are equipped with the knowledge and technologies by means of which nature and its biodiversity are conserved, enhanced and sustainably utilized. The farmers have never kept their farming systems in static state. They have changed themselves and their systems as per specific circumstances. They have evolved strategies as per the local specificities and that can cope up with adverse circumstances.

\section{Food Security Concept in Mountain Context}

Just three food crops - wheat, rice, and maize - meet about 75 percent of the total energy humanity worldwide needs for 
sustenance. This perhaps is the most precarious situation relating to food security on a global scale. Any imbalance in the production of these three food grains - due to some epidemic or some ominous changes in climate, for example - might pose a serious threat to the very survival of human race. Some unique food crops endemic to certain regions are being squeezed out of cultivation practices to give a room for the alien cultivars and some non-food cash crops having "high" market value.

The concept of food security - the ability of a household to get access to enough food for all its members, either by producing it or by earning enough to buy it - has been given new meaning in the food-deficit regions of the Himalayas where farmers are being encouraged to grow high value cash crops which will contribute to their incomes and thus their food purchasing power. This "new meaning", in fact is a bid to amalgamate the local realities with the globalization process. This emphasises only the "food purchase power", a mere political dimension of "food security" indiscriminately imposing a dependence on market. It has no respect for local cultures and reverential attitude towards pristine marginal ecosystems like the mountains. "High-value" cash crops are not the ones mountain farmers have been growing for millennia. These are the ones that require exploitation of unique ecological niches wantonly to serve the interests of the global elites in the first place.

There can be no standard approach for food security on a global scale. Food security without cultural roots is not sustainable. And the current market-linked concept of food security being debated the world over has no cultural roots; i.e., it has no consideration of specific ecosystem features and the communities evolved therein. Food situation is tied with local realities. Local considerations rather than global "standards" would add to the essential cultural dimension to food security. Mountain farmers are accustomed to grow diversity of food in their habitats, in harmony with specific ecological niches for specific products and activities. Diversity in sources providing food is the very essence of the food security of mountain cultures. A community has its own food habits. As such, there exists an enormous diversity in food habits of peoples in the world. You cannot ensure food security of a Westerner by plenty of rice for him. A vegetarian cannot be provided food security through meat. Food security in Uttarakhand would be meaningless without Dal-Bhaat. A community's food habits match with the food production system it has evolved in its habitats. Provision of food as per food habits is a must for one's physical and mental development and psychological satisfaction.

Food security of masses in India as of today is tied with just two types of food grains - wheat and rice - supplied to the vulnerable sections of the society through public distribution system (PDS). PDS, in fact, appears to have become the only political perception of "food security". Inaccessibility- and fragility-ridden mountain areas require altogether a different approach for acquiring sustainability and food security. Majority of the population in Uttarakhand is land-based. They are small and marginal farmers depending on a variety of foodproviding sources: the CPRs, the croplands, the livestock, and the water bodies.

Diversified agriculture is the best bet for reducing risks and enhancing the degree of security. The marginal farmers exactly do the same. The gains accrued to the small and marginal farmers through diversified agriculture, however, are limited by the size of the arable land they own. But, it is not the arable land alone that could serve as the base for food security as is perceived in the context of the plains. Mountain farmers give equal, rather greater, importance to the CPRs, other marginal ecosystems (alpine meadows, for example), and water sources.

Availability of water on sustained basis is a prerequisite for sustainable food security. For water security, fragile mountains obviously require high density of climax vegetation with enormous diversity of all types of plants - trees, shrubs, herbs, creepers, etc. Such vegetation, in addition to contribute biomass to cropland so crucial for soil fertility management, also responds to the problems associated with fragility of the Himalayan mountain ecosystems.

High degree of inaccessibility of the mountain areas calls for decentralized economies. Dependence on a central market place for agricultural inputs and food grains is not only difficult and energy consuming but also not conducive to the very philosophy of food security.

Self-sufficiency in food has to be the foremost target to food security in mountain ecosystems. And for this to achieve, farming system approach of food production involving local farming cultures should be the focal point of our strategies.

In marginal areas, food self-sufficiency of farming households should be preferred over food purchase power. Farmers have ample opportunities for raising their incomes through what their ecological niches can offer. These can range from off-season vegetables, to vegetable seed production, to floriculture, to medicinal and aromatic plants, and so on. These cash-promising activities would raise their purchasing power. However, these should be compatible with the food selfsufficiency in the region.

\section{Adaptation Capabilities of Mountain Agriculture}

The farming system the local farmers have developed is characterized by specific adaptation mechanisms. Farmers through their specific management practices have ensured maintenance of the sustainability characteristics of a farming system. These are ensured through energy, nutrient, water and gaseous flows within the ecosystem (Figure 3). These flows are indispensable for ecological integrity of the farming system. 


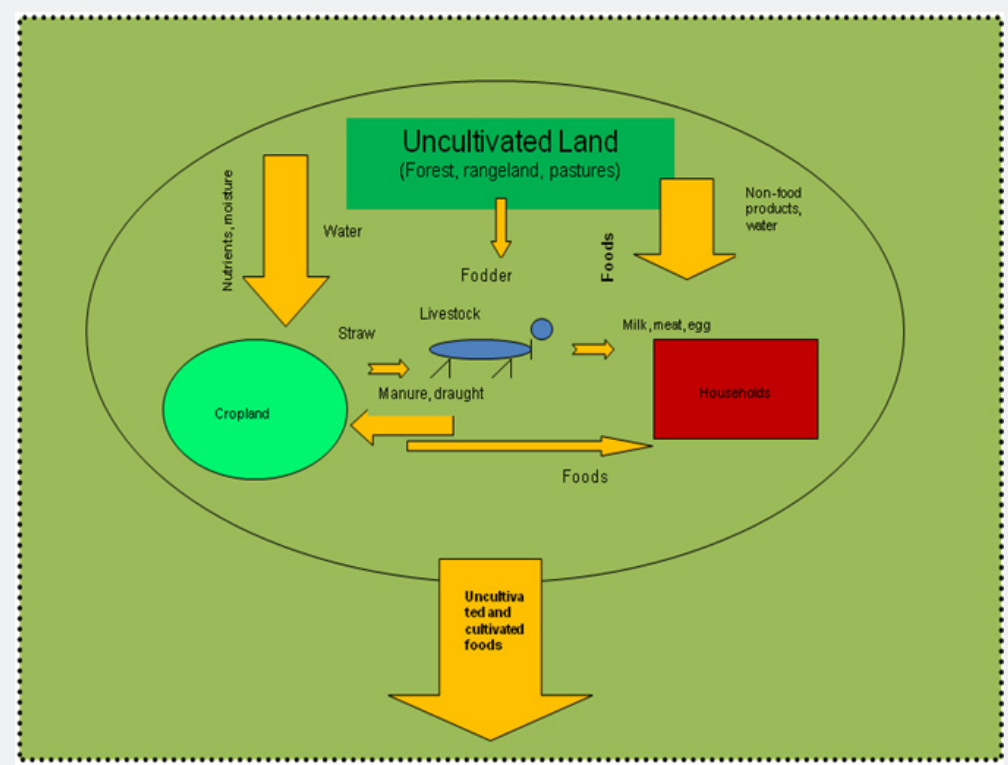

Figure 3: A mountain agro-ecosystem: linkages between components/ subsystems, nutrient and water flows maintain ecological integrity and sustainability of the food production system.

Mountain agriculture adaptation capabilities can be counted at two points, viz., resource base and farmers' response. Resource base imparting adaptation capability includes common property resources, landraces, Baranaaja culture, and livestock. The farmers' response includes farming system approach, community based farming, on-farm biodiversity conservation, and farmers' knowledge, strategies and innovations. These are elaborated in Table 3 and depicted in Figure 4.

Table 3: Mountain agriculture capabilities and their attributes.

\begin{tabular}{|c|c|}
\hline $\begin{array}{l}\text { Mountain Agriculture } \\
\text { Capability }\end{array}$ & Attributes of the Adaptation Capability \\
\hline & Resource Base \\
\hline \multirow{6}{*}{ Common property resources } & Vital for the ecological integrity of an agro-ecosystem \\
\hline & Micro-climate maintenance \\
\hline & Repository of nutrients, energy and water/Moisture \\
\hline & Natural fodder bank for livestock \\
\hline & $\begin{array}{l}\text { Wild fruits, nuts, edible flowers, buds, mushrooms, uncultivated vegetables, seeds, pods, beans, medicinal } \\
\text { and aromatic plants, honey, etc. }\end{array}$ \\
\hline & $\begin{array}{c}\text { Supply of raw material for house construction, domestic fuel, agricultural implements and tools and cottage } \\
\text { industries }\end{array}$ \\
\hline \multirow{4}{*}{ Landraces } & Extremely adapted for the local conditions \\
\hline & High genetic diversity \\
\hline & Nutritive value, specific aroma and taste \\
\hline & Medicinal value of some crops \\
\hline \multirow{7}{*}{ Baranaaja Culture } & Cultivation of biodiversity \\
\hline & Soil fertility management \\
\hline & Insect-pest management \\
\hline & Production of high energy, protein- and nutrient-rich foods (millets, pseudo-cereals, pulses, beans, etc.) \\
\hline & Resistance against drought conditions \\
\hline & Use of degraded, nutrient-poor soils \\
\hline & Spatial and temporal utilization of cultivated land \\
\hline
\end{tabular}


Nutrition \& Food Science International Journal

\begin{tabular}{|c|c|}
\hline \multirow{6}{*}{ Livestock } & Diversification of food resources \\
\hline & Utilization of high fibrous diet \\
\hline & Mediation for nutrients from ecologically more stable forest ecosystem to fragile croplands \\
\hline & Recycling of nutrients into croplands \\
\hline & Supply of draught power for ploughing, leveling, puddling, inter-culture, etc. \\
\hline & Acting as cushions against economic adversity \\
\hline \multicolumn{2}{|r|}{ Farmers' Response } \\
\hline \multirow{5}{*}{ Farming system approach } & Ecological stability, reduced vulnerability, enhanced resilience \\
\hline & Diversification of food production \\
\hline & Provision of inputs from within the system \\
\hline & Risk reduction \\
\hline & Sustainability operation \\
\hline \multirow{7}{*}{ Community based farming } & Participation of whole community \\
\hline & Democratic decision making in resource management \\
\hline & Availability of precious resources such as seeds at reasonable rates, or free of cost, or through bartering \\
\hline & Free exchange of resources (e.g., ploughshare, germplasm, bullocks, etc.) \\
\hline & More emphasis on innovative approaches to resource management \\
\hline & Involvement of community's feelings, aspirations and future dreams \\
\hline & Enhancement of social cohesion \\
\hline \multirow{6}{*}{$\begin{array}{l}\text { On-farm biodiversity } \\
\text { conservation }\end{array}$} & Maintenance of the inherent/Natural characters of germplasm \\
\hline & Minimisation of risks of species' extinction \\
\hline & Conservation of biodiversity in a natural way \\
\hline & Control of farming community on resource conservation and utilization \\
\hline & Reduced dependence on market/Corporate sector for expensive and often unaffordable germplams \\
\hline & Maintenance of endemic diversity in nature \\
\hline \multirow{6}{*}{$\begin{array}{l}\text { Farmers' knowledge, } \\
\text { strategies, innovations }\end{array}$} & Conservation, transfer, articulation and promotion of traditional community knowledge \\
\hline & Articulation of traditional wisdom in land-based activities \\
\hline & Risk minimization tactics of farming \\
\hline & Experimentation according to local site characteristics \\
\hline & Application of world view of agriculture \\
\hline & Applications of community's own research methodologies and technology testing \\
\hline
\end{tabular}

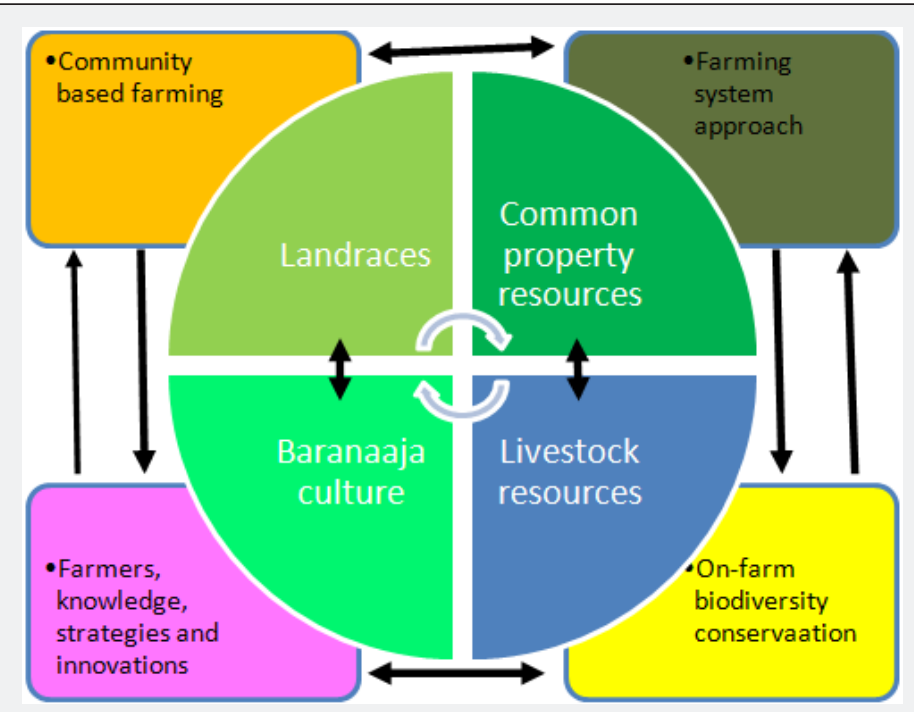

Figure 4: Adaptation capability of mountain agriculture. 
The Cycle of Sustainability

\begin{tabular}{|c|c|} 
Living soil & $\begin{array}{c}\text { Bodiversity- } \\
\text { complexity }\end{array}$ \\
Figure 5: Cycle of sustainability & \\
increment & $\begin{array}{c}\text { Cyclic flows } \\
\text { of nutrients }\end{array}$ \\
\hline
\end{tabular}

There are three principles of sustainability operationalisation-Living soil, biodiversity and cyclic flow pattern of nutrients. Mountain farmers manage the soil in such a way that it should continue to be replenished by nutrients through manure, recycling, in-situ fertilization mixed cropping, mulching and other management practices. They still adhere to an old adage - don't feed the plant, feed the soil which feeds the plant. Farmers cultivate as much agrobiodiversity as could be possible in a particular area. They also manage the natural biodiversity in uncultivated areas (forests, grasslands, rangelands, etc.). This biodiversity is a key to sustainability. Higher the degree of biodiversity, higher the level of sustainability. Farmers also manage cyclic flows of nutrients. Whatever nutrients are extracted from croplands are cycled into the same soil through manure. The soil fertility is further enhanced by supplementing the nutrients from forest soil.

This wonderful practice of farming in mountain areas is an example of farmers' management of sustainability (Figure 5), which is a natural adaptation capability in the region.

\section{Agro-ecophilosophy and Sustainable Biosphere}

Agriculture, in essence, is an articulation of a philosophy we can call agro-ecophilosophy. Agro-ecophilosophy is a meaningful fusion of agriculture, ecology and philosophy. This philosophy is life-enhancing and has been at the heart of Indian ethos for millennia and embraces reverential attitude towards nature, ecosystems, and whole life [3].

Agro-ecophilosophy provides basis for ecological consciousness which is a pre-requisite of ecological responsibility. Ecological responsibility prepares a ground for pertinent ecological actions, which are essentially the life-enhancing actions (biodiversity conservation and enhancement, for example). Ecological action directs us for ecological justice, which, in turn, provides an atmosphere of ecological culture. The ecological culture would help create an ecological balance. And ecological balance is an absolute need for a sustainable biosphere (Figure 6).

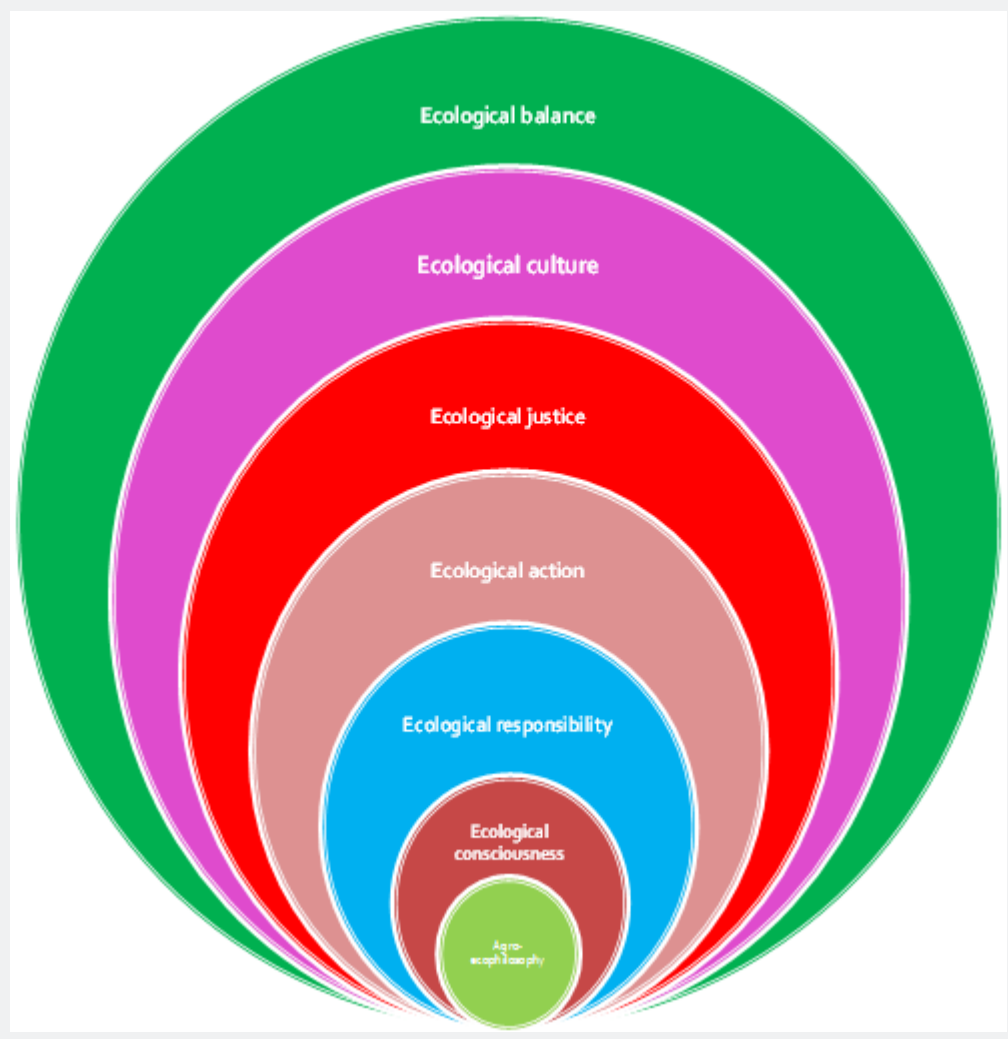

Figure 6: Agro-ecophilosophy, agri-culture and sustainable biosphere. 
Mountain farming communities have been creating ecophilosophies for centuries. Himalayas' serenity, environmental sacredness and scenic beauty have been inspiring them to create and implement eco-philosophies. Mountain agriculture in its traditional form still sings a song of mountain farmers' philosophy. The agro-ecophilosophy is potent enough to heal the Earth and to restore our glorious agriculture even in the era of global warming and climate change.

\section{Conclusion}

The natural and farmer-evolved adaptation capabilities of mountain agriculture, as discussed in this paper, serve as a part of our strategy of rising against global warming in our times. The mountain culture has not undergone as much drastic change as the mainstream agriculture. With specific characteristics of the mountain resource base and farmers' traditional strategies implemented honestly on a massive scale, we would be able to regenerate the productive potential of the traditional mountain agriculture. We need to capture and absorb basic philosophical elements of the traditional mountain agriculture, i.e., the agro-ecophilosophy, to regenerate and restore the kind of agriculture which could produce a variety of plentiful foods to nourish local communities as well as the people in the distant areas. In this way we would not only rise against the global warming but would also come out with a glorious victory to restore the original evolutionary gesture of our nature.

\section{References}

1. Singh V (2010) Mountain Agriculture and Adaptation Capabilities: Rising Against Global Warming. In: Shiva, Vandana \& Bhatt, VK (Eds.), Climate Change at the Third Pole: The Impact of Climate Instability on Himalayan Ecosystems and Himalayan Communities, New Delhi: Navdanya, India, pp. 153-162.

2. Singh V (2005) Agrobiodiversity, Sustainability and Food Security in the Himalayan Mountains: An Uttaranchal Perspective, Gorakhpur: Gorakhpur Environmental Action Group, p. 50.

3. Singh V, Nautiyal N, Rastogi A (2012) Callous Development and Climate Disruption: Environmental Management for Healing the Earth and Restoring Climate Pattern. In: Nautiyal N, et al. (Eds.), In: Environmental Management: Meeting the Challenges of Climate Change, SSDN, New Delhi, India p. 11-20.

\begin{tabular}{l} 
Your next submission with Juniper Publishers \\
will reach you the below assets \\
- Quality Editorial service \\
- Swift Peer Review \\
- Reprints availability \\
- E-prints Service \\
- Manuscript Podcast for convenient understanding \\
- Global attainment for your research \\
- Manuscript accessibility in different formats \\
( Pdf, E-pub, Full Text, Audio) \\
- Unceasing customer service \\
Track the below URL for one-step submission \\
https://juniperpublishers.com/online-submission.php \\
\hline
\end{tabular}

